\title{
Assessment of Shear Strength from Measuring While Drilling Shafts in Florida Limestone
}

\begin{tabular}{|r|l|}
\hline Journal: & Canadian Geotechnical Journal \\
\hline Manuscript ID & cgj-2017-0629.R1 \\
\hline Manuscript Type: & Article \\
\hline Date Submitted by the & $26-$ Mar-2018 \\
\hline $\begin{array}{r}\text { Complete List of Authors: } \\
\text { Rodgers, Michael; University of Florida, Civil Engineering; } \\
\text { McVay, Michael; University of Florida } \\
\text { Horhota, David; Florida Department of Transportation, State } \\
\text { Materials Office - Geotechnical and Materials } \\
\text { Sinnreich, Jon; University of Florida, Civil Engineering } \\
\text { Hernando, Jose; Florida Department of Transportation, State } \\
\text { Materials Office }\end{array}$ \\
\hline $\begin{array}{r}\text { Is the invited manuscript } \\
\text { for consideration in a } \\
\text { Special Issue? : }\end{array}$ & Not applicable (regular submission) \\
\hline Keyword: & $\begin{array}{l}\text { Drilled Shaft, Rock Auger, Measuring While Drilling, Florida } \\
\text { Limestone, Specific Energy }\end{array}$ \\
\hline
\end{tabular}




\title{
Assessment of Shear Strength from Measuring While Drilling Shafts in Florida Limestone
}

\author{
Authors: \\ ${ }^{1}$ Michael Rodgers, michael.rodgers@essie.ufl.edu \\ ${ }^{1}$ Michael McVay, mcm@ce.ufl.edu \\ 2David Horhota, david.horhota@dot.state.fl.us \\ ${ }^{1}$ Jon Sinnreich, jon.sinnreich@essie.ufl.edu \\ ${ }^{2}$ Jose Hernando, jose.hernando@dot.state.fl.us
}

\begin{abstract}
Affiliations:
${ }^{1}$ University of Florida - Herbert Wertheim College of Engineering Engineering School of Sustainable Infrastructure \& Environment 300 Weil Hall, P.O. Box 116550, Gainesville, Florida 32611

${ }^{2}$ Florida Department of Transportation - State Materials Office 5007 Northeast 39 ${ }^{\text {th }}$ Avenue, Gainesville, Florida 32609
\end{abstract}

Corresponding Author:

Michael Rodgers

365 Weil Hall, Gainesville, Florida, 32611

$352-422-3882$

$\underline{\text { michael.rodgers@essie.ufl.edu }}$ 


\section{Abstract}

The focus of this research is the real time assessment of drilled shaft capacity based on the unconfined compressive strength $\left(q_{u}\right)$ obtained from measuring while drilling (MWD). Measures of $q_{u}$, a function of rock strength commonly used in drilled shaft design, are provided through five monitored drilling parameters: torque, crowd, rotational speed, penetration rate, and bit diameter. Monitored shaft installations took place at three separate locations on drilled shafts which were subsequently load tested. Using the $q_{u}$ values obtained from MWD, side shear was estimated in portions of each shaft where instrumented segments indicated the side shear was fully mobilized for direct comparison.

In order to consider all of the current side shear equations used in Florida drilled shaft design, the estimation of tensile strength $\left(q_{t}\right)$ in real time was also needed. This led to a theoretical approach to establish the $q t / q_{u}$ relationship which was later verified empirically and provided new correlations between material and mechanical properties of Florida geomaterials.

A comparative analysis indicated that the results from multiple established side shear equations, used with $q_{u}$ from MWD, align well with the results obtained from load testing. This suggests that estimating drilled shaft capacity from MWD is viable to reduce spatial uncertainty.

\section{Keywords}

Drilled Shaft, Rock Auger, Measuring While Drilling, Florida, Limestone 


\section{Introduction}

This paper explores using measurements of unconfined compressive strength, obtained from measuring while drilling shafts, to estimate side shear capacity in real time. The research discussed is part of a larger project that included a laboratory and field drilling investigation using rock augers. From the laboratory investigation, a unique relationship was developed between specific energy (Teale 1965) and unconfined compressive strength, $q_{u}$, for Florida limestone (Rodgers et al. 2017a). Specific energy, $e$, is provided in real time by continuously measuring five drilling parameters: torque, crowd, rotational speed, penetration rate, and bit diameter. The e vs. $q_{u}$ equation developed from the unique relationship was used during field drilling to assess $q_{u}$ in real time at three separate locations where each monitored drilled shaft was subsequently load tested (Rodgers et al. 2017b):

1. The Little River Bridge site in Quincy, FL.

2. FDOT's Kanapaha site in Gainesville, FL.

3. The Overland Bridge site in Jacksonville, FL.

The focus of the field investigation was to evaluate the monitored drilling process and compare the shaft capacity estimates obtained from measuring while drilling (MWD) with conventional methods such as load tests and core data. This portion of the research covers estimating skin friction in real time through MWD and comparing the results obtained from load testing the monitored shafts. This paper also discusses new correlations developed between material properties and mechanical properties of Florida geomaterials which includes limestone, intermediate geomaterial (IGM), and over-consolidated clays. 


\section{Background}

In drilled shaft design, the capacity of each shaft is developed from a combination of end bearing $\left(q_{b}\right)$ and side shear $\left(f_{s}\right.$, commonly referred to as "skin friction"). Axial loads applied to the top of a drilled shaft are transferred to the ground through each resistance mechanism as shown in Figure 1. where,

- $\quad P=$ Axial load (kN)

- $\quad W=$ Weight of the shaft $(\mathrm{kN})$

- $f_{s}=$ Side shear or skin friction $(\mathrm{kPa})$

- $q_{b}=$ End bearing $(\mathrm{kPa})$

Load transfer through skin friction is the result of a combination of cohesion and adhesion at the rock-shaft interface. Load transfer through end bearing is the result of compressive loading between the bottom of the drilled shaft and the soil/rock. Although large shaft capacities can be generated through end bearing, due to several factors it is common practice in Florida to design drilled shafts solely using skin friction. These factors include: a possible lack of rock layer uniformity beneath each shaft, the possibility of inadequate clean-out at the base of the shaft during excavation leading to a "soft toe" condition, and most importantly the unacceptably large amount of shaft displacement required to fully mobilize end bearing based on LRFD service limits (AASHTO 2009; Brown et al. 2010; Chung et al. 2012).

In skin friction design, it is common practice to use average layer properties. This allows the engineer to consider multiple rock layers over the span of the shaft, and provides a versatile design approach to account for a high degree of variability. Similar 
to end bearing, large shaft capacities can also be achieved through rock socketed side shear. However, the associated shaft displacements are typically less than 1.27 centimeters (half an inch), which satisfies the LRFD service limits (Brown et al. 2010), and ensures the structure supported by the shaft will experience limited settlement.

When designing drilled shafts, there are numerous methods for estimating skin friction; and typically each equation is only used for a specified material type (e.g., sand, clay, or rock). In most cases, equations developed for rock and IGM use $q_{u}$ to estimate side shear capacity (Brown et al. 2010). Therefore, providing real time measurements of $q_{u}$ allows the engineer to choose from multiple equations commonly used in design to assess shaft capacity in real time as well. The equations are generally formed using empirical methods and presented in one of the following two ways:

Using a linear function to develop the equation,

$f_{s}=a * q_{u}$

Or using a power function to develop the equation,

$f_{s}=a * q_{u}^{b}$

where $a$ and $b$ are empirical constants developed using load test data from instrumented drilled shafts. In the pursuit of an accurate method to determine skin friction in real time during field drilling, several of the more common equations used in Florida drilled shaft design were considered for the analysis (Table 1).

\section{Incorporating the $q_{t} / q_{u}$ Ratio into Skin Friction Estimates}

As seen in Table 1, all methods use only $q_{u}$ to estimate skin friction except McVay et al. (1992), which also incorporates tensile strength, $q_{t}$. Using a parametric finite-element method, McVay investigated the maximum side shear at the rock-shaft 
interface, where he indicated the cohesion of rock is a closely approximated estimate of the failure side shear. However, in order to determine the cohesion of rock, knowledge of the friction angle is typically needed which is not readily available. Generally, this requires more than one laboratory strength test to be performed. For example, multiple triaxial compression tests at different confining pressures would be one option, but this is a very time consuming process. Alternatively, McVay proposed a more simplistic approach using results from unconfined compression and split tension testing implemented on field cores, which are readily available from typical site investigation. He found that the failure of rock can be described through a Mohr-Coulomb strength envelope; leading to the development of an alternative model based on split tension and compressive strength test data.

When compared to conventional test methods, McVay found excellent agreement between results obtained using Method 1 (Table 1 ) with existing $q_{u}$ and $q_{t}$ data and the results obtained from 53 pullout tests and 7 load tests at 14 different sites in Florida. Furthermore, the method was developed specifically for Florida limestone socketed drilled shafts and recently became the recommended design method in the Florida Department of Transportation (FDOT)'s Soils and Foundation Handbook ("SFH"; FDOT, 2015). Since McVay et al. is the SFH recommended design method, measures were taken to ensure the equation could be used for the drilled shaft field monitoring comparative analysis, which required real time measurements of tensile strength.

Similar to the $e$ vs. $q_{u}$ equation developed in Rodgers et al. (2017a), an $e$ vs. $q_{t}$ equation was also developed. However, the material formation of synthetic limestone used during laboratory drilling was found to provide a higher $q_{t} / q_{u}$ ratio than is typical of 
Florida limestone. This was confirmed in preliminary skin friction analysis at Little River, where McVay et al. used with the laboratory-developed $e$ vs. $q_{t}$ equation, consistently produced overestimates of side shear. Consequently, alternative methods for determining the $q_{t} / q_{u}$ ratio were investigated.

\section{Developing the $q_{t} / q_{u}$ Ratio from Boring Data}

The first method grouped pairs of $q_{u}$ and $q_{t}$ values that were collected in the same general vicinity within each approximate 1.5-meter core run, for every boring completed at a site. This was done in an attempt to provide a range of $q_{t}$ values for each recorded $q_{u}$ value. Once all the pairs were created, the $q_{t} / q_{u}$ ratio was calculated for each pair. Any $q_{t} / q_{u}$ value which fell outside of one standard deviation from the mean was removed. Remaining pairs from each boring location were then combined, removing the outliers again, and used to plot $q_{t}$ vs. $q_{u}$ to determine the $q_{t} / q_{u}$ ratio for the entire site (Figure 2).

Using the curve-fit $q_{t} / q_{u}$ ratio, skin friction was estimated in four segments along the test shaft at the Little River Bridge site where load test results indicated the side shear was mobilized in layers of limestone (Table 2).

As evident in Table 2, using McVay with the developed $q_{t} / q_{u}$ ratio provided an excellent result. In all four mobilized sections of the drilled shaft, the results obtained from monitoring the shaft installation were in close agreement with the Osterberg load test results. The range of unit side shear values, from all four sections, was indicative of the variability at the site and monitoring was able to distinguish the layers. However, the validity and practicality of the method to determine the site $q_{t} / q_{u}$ ratio was in question. Using this approach, the compressive strength values may be paired with 
split tension values from two dissimilar materials when developing the $q_{t} / q_{u}$ ratio. The $q_{t} / q_{u}$ ratio developed also does not account for the overestimation of tensile strength that split tension testing provides (Perras and Diederichs 2014). Both cases would provide inaccurate $q_{t} / q_{u}$ ratios and shaft capacity estimates in other locations with less available core data. For example, in Table 3 the highlighted portion indicates a $q_{u}-q_{t}$ pair that would be used to determine the average $q_{t} / q_{u}$ ratio for a layer or site to provide $q_{t}$ for use with the equation. However, upon inspection of the dry unit weights and moisture contents of the two test results, it is clear that these are dissimilar materials that should not be combined and used to determine the $q_{t} / q_{u}$ ratio. This led to a more theoretical approach to develop $q_{t}$ estimations based on Johnston's (1985) criterion.

\section{Development of the Florida Geomaterials Equation}

Johnston investigated the strength of intact geomaterials, where he found that a number of strength criteria can describe the strength of geomaterials and that each criterion is typically limited to certain materials types with a limited range of stress conditions. Johnston proposed a new empirical strength criterion that was applicable to a wide variety of intact geomaterials, from lightly overconsolidated clays to very hard rock, for both compressive and tensile stress regions. His new criterion demonstrated that the strength of these largely different geomaterials followed a distinct progressive pattern.

Based on Johnston's criterion for geomaterials, a $q_{t} / q_{u}$ vs. $q_{u}$ plot was developed by Anoglu et al. (2006) for the concrete industry, indicating $q_{t} / q_{u}$ ratios decrease as compressive strength increases and that the trend is nonlinear. Anoglu et al. tested various concrete samples that were developed using different water-to-cement ratios, 
binders, additives, cure times, and curing conditions, which is similar to the various limestone formations found throughout Florida. Specifically, each geological formation is a unique matrix comprised of different binding material concentrations, different constituents within the rock matrix such as clay found in North Florida that is not found in South Florida, various formation ages ranging from less than 1 million years to over 35 million years, various curing conditions such as changing sea level or the amount of overburden present above the formation, as well as different skeletal remains left behind that act as the aggregate and provide the main source of binder from calcite precipitate.

In Johnston's report, he indicated a similar $q_{t} / q_{u}$ vs. $q_{u}$ relationship could be determined for all geomaterials. Therefore, using Johnston's proposed criterion, an equation similar to Anoglu et al.'s was developed for Florida geomaterials. The equation development began using Johnston's relationship for $q_{t} / q_{u}$ ratios.

$$
q_{t} / q_{u}=B / M
$$

where,

- $q_{t}=$ Uniaxial tensile strength (direct tension)

- $q_{u}=$ Uniaxial compressive strength

- $B$ is a material parameter developed by Johnston that defines the nonlinearity of the Mohr-Coulomb failure envelope and is a measure of confinement effectiveness. $B$ is independent of material type.

- $M$ is also a material parameter developed by Johnston, and defines the changes in failure stresses associated with different geomaterial types (i.e., the 
relationship between $\Phi^{\prime}$ and $q_{u}$ that would be obtained from multiple triaxial tests).

Johnston developed a single equation for $B$,

$B=1-0.0172\left(\log q_{u}\right)^{2}$

where $q_{u}$ is measured in kilopascals $(\mathrm{kPa})$, and developed multiple equations for $M$ based on material groupings such as; carbonate materials with well-developed crystal cleavage (e.g., limestone and dolomite),

$M=2.065+0.170\left(\log q_{u}\right)^{2}$

lithified argillaceous materials (e.g., overconsolidated clay, claystone, and mudstone),

$M=2.065+0.231\left(\log q_{u}\right)^{2}$

and arenaceous materials with strong crystals and poorly developed crystal cleavage (e.g., sandstone and calcarenite),

$$
M=2.065+0.270\left(\log q_{u}\right)^{2}
$$

With the understanding that Florida field drilling would likely pass through varying layers of each material group, all three $M$ equations were considered for the development of the Florida geomaterials $q_{t} / q_{u}$ vs. $q_{u}$ relationship. Using Johnston's equations for $M$ and $B$, the following regression curves and equations (Figure 3 ) were developed for each material group using $q_{u}$ values ranging from approximately 7 to 70 $000 \mathrm{kPa}$ (1 to $10000 \mathrm{psi})$.

Evident in Figure 3, the shape and $q_{t} / q_{u}$ ratios of the three regression curves are different with respect to $q_{u}$. Of interest was developing a single equation that was representative of all three curves to provide a good approximation of tensile strength 
(and therefore skin friction) in real time, regardless of the Florida geomaterial type encountered. The approach seemed justified as Johnston's limestone equation, used with McVay, produced overestimates of skin friction at Little River, where small varying layers of OC clay, IGM, and limestone were encountered. The overestimates were thought to be a result of Johnston's limestone data sets not including any samples from Florida to develop the equation. The limestone and dolomite data sets Johnston used to develop the equation had a compressive strength range of approximately $37000 \mathrm{kPa}$ to $517000 \mathrm{kPa}$. This would be considered very high strength limestone in Florida, even for the low end of the range $(37000 \mathrm{kPa})$. The frequency distribution presented in Figure 4, which includes $q_{u}$ data collected from 23 different sites throughout Florida, indicates that over $90 \%$ of Florida limestone has a compressive strength less than $35000 \mathrm{kPa}$. This led to the conclusion that Johnston's limestone data sets (carbonate materials) lacked the necessary low strength data needed to properly develop the relationship over the full compressive strength range. However, Johnston stated that despite the apparent radical differences between lightly overconsolidated clays, extremely hard rocks, and all the materials in between, their intact strength variations may be a matter of degree rather than of a fundamental nature. The statement suggests that a single equation could be developed to describe the mechanical behavior of all three sedimentary rock groups. Interestingly, Johnston's OC Clay and IGM data sets (argillaceous materials) included siltstone, claystone, mudstone, marl, and OC clay, which are commonly found in central and North Florida, while his Sandstone data sets (arenaceous materials) included sandstone and calcarenite (e.g., oolite and sandy limestone) which are found in South Florida and coastal areas. Moreover, considering all three data sets extends 
the compressive strength range from 10 to $517000 \mathrm{kPa}$. Consequently, a new $M$ equation was developed that is representative of all three material groups.

Equation development was completed using only data (core, load test, and MWD) collected at the Little River Bridge site, where varying layers of OC clay, IGM, and limestone were encountered which is representative of two of Johnston's sedimentary $M$ equations. Additionally, recovered cores from the site indicated a compressive strength range of approximately 30 to $30000 \mathrm{kPa}$ which accounts for nearly $90 \%$ of Florida limestone compressive strengths (Figure 4). Johnston's limestone $M$ equation was adjusted to align the side shear prediction (MWD) with the load test data and a best fit equation was derived for simplified calculation, similar to Figure 3 . The adjustment began by plotting data points $\left(q_{t} / q_{u}\right.$ vs. $\left.q_{u}\right)$ in the $q_{u}$ axis based on measured $q_{u}$ values from the cores extracted at the Little River site. This placed emphasis in various portions of the $q_{u}$ range which are commonly encountered in Florida's highly variable geological formations. As a result, the log multiplier in Johnston's limestone $M$ equation was reduced from 0.170 to 0.158 , and the curve was reshaped to reflect natural Florida conditions. Reduction factors were then applied to the newly derived best fit equation until the predicted side shear aligned with the load test results which produced the following equation,

$$
M=3.304+0.158\left(\log q_{u}\right)^{2}
$$

where $q_{u}$ is measured in kilopascals $(\mathrm{kPa})$.

As seen in Equation 8, aligning the side shear prediction increased Johnston's asymptotic $M$ value of 2.065 to 3.304 . Johnston stated in his report that it was quite feasible that the asymptotic value could range from 1.8 to 3.7 , and the adjustment 
seems reasonable. Interestingly, the increased value reduces the $q_{t} / q_{u}$ ratio as $q_{u}$ approaches zero and provides a similar $q_{t} / q_{u}$ relationship to Johnston's sandstone equation at lower compressive strengths, even though arenaceous materials were not encountered at the site. The resulting curve now transitions through the Sandstone and OC Clay and IGM curves at lower compressive strengths, and provides a similar $q_{t} / q_{u}$ relationship to Johnston's Limestone equation at higher compressive strengths. This can be seen in Figure 5, where the new Florida Geomaterials $M$ equation (Equation 8) is compared to the original equations from all three material groups.

Evident in Figure 5, the $q_{t} / q_{u}$ ratios for the lower end $q_{u}$ values are more representative of the sandstone curve and as $q_{u}$ increases the $q_{t} / q_{u}$ ratios become representative of the OC Clay and IGM curve. As $q_{u}$ progresses further, the Florida Geomaterials curve gradually becomes more representative of Johnston's original Limestone curve. Therefore, the side shear alignment approach, using only data collected at Little River, produced a new $M$ equation that is representative of all three of Johnston's sedimentary relationships. It should be noted that the developed $M$ equation is not intended to define a specific sedimentary material group within a specified portion of the $q_{u}$ range; rather it is to provide a general $q_{t} / q_{u}$ relationship for Florida sedimentary rocks within a $q_{u}$ range typical of Florida conditions. The purely theoretical relationship was further investigated on this basis.

\section{Investigation of the New Florida Geomaterials $q_{t} / q_{u}$ Correlations}

From the FDOT bridge foundation database, extensive core data was available to investigate the $q_{t} / q_{u}$ relationship of Florida geomaterials (as partially summarized in Figure 4). Of particular interest was the $q_{t} / q_{u}$ relationship from the database compared 
to the Florida Geomaterials relationship when similar moisture contents and dry unit weights are considered. Based on the logic of Table 3, it stands to reason both material properties can be used to identify similar geomaterials, which should allow the $q_{t} / q_{u}$ relationship to be properly investigated. For instance, the dry unit weight indicates that similar materials make up a rock mass (i.e., similar mineralogy; Perras and Diederichs 2014) and when combined with moisture content the properties become representative of the void ratio and porosity of the material, which should be indicative of the void structure. This is confirmed by the $G w=$ Se condition for geomaterials (Lambe and Whitman 1969). Furthermore, it has been well documented that an increase in moisture content/porosity reduces mechanical strength properties (Baud et al. 2014; Chen et al. 2013; Rajabzadeh et al. 2012; Vasarhelyi and Van 2006; Wong et al. 2016; Yilmaz 2010). Therefore, correlations between material properties and mechanical properties were investigated using approximately 1,200 laboratory tested $q_{t}$ values and 700 laboratory tested $q_{u}$ values from the following project sites in Florida.

- 17th Street Causeway

- Acosta Bridge

- BR720153 SR-9 (I-95) Overland

- CR-326 @ Waccasa River

- HEFT / SR 874 PD\&E

- I-295 Buckman Bridge

- I-295 Dames Point Bridge

- I-95 @ I-295 Cloverleaf

- I-95 Fuller Warren Bridge 
- Jewfish Creek

- MIC- People Mover Project

- NW 12th Ave (SR 933) Miami River Bridge

- NW 36th Street Bridge

- Pump Station at Bal Harbour (96th St \& Indian Creek)

- Radio Tower Everglades Academy (Florida City)

- SR-10 @ CSX RR (Beaver St. Viaduct), Duval Co.

- SR-20 @ Lochloosa Creek, Alachua Co.

- SR-25 @ Santa Fe River

- SR30/US98 @ Aucilla River

- SR-9 (I-95) Overland Bridge

- US-90 Victory Bridge

- Verona Ave Bridge Over Grand Canal

- Wall at Service Road South of Snake Creek

For the investigation, each individual $q_{u}$ and $q_{t}$ value from the data set were grouped in ranges based on their material properties, moisture content and dry unit weight. For moisture content, the ranges were grouped in increments of $2 \%$ (e.g., w\% $=$ $0 \%$ to $2 \%, 2 \%$ to $4 \%$, etc.). For dry unit weight, the ranges were grouped in increments of approximately $0.8 \mathrm{kN} / \mathrm{m}^{3}$ (e.g., $\gamma_{d}=14.9 \mathrm{kN} / \mathrm{m}^{3}$ to $15.7 \mathrm{kN} / \mathrm{m}^{3}, 15.7 \mathrm{kN} / \mathrm{m}^{3}$ to 16.5 $\mathrm{kN} / \mathrm{m}^{3}$, etc.). For each material property range, the average and standard deviation were derived and used to establish an acceptable strength range for both $q_{u}$ and $q_{t}$ which is used as an index reference for strength. The mechanical properties were then plotted as a function of each material property, and regression equations were 
developed using a best-fit power function derived from the averages of each material property range, Figures 6 through 9 . The average values were used to remove the influence of a specific material property range with more collected data affecting the overall relationship, thus allowing the typical strengths obtained within each material property range to be compared directly without bias.

As seen in all four Core Data Index (CDI) plots, both material properties do influence both mechanical properties. The r-squared values derived in each CDI plot indicate that dry unit weight provides better correlation with $q_{u}$ and $q_{t}$ than does moisture content. Also observed in all cases except Figure 7, the regression curves plotted within one standard deviation from the mean of each material property range. The averages within each material property range in Figure 7 could have been more accurately defined through a linear or higher order polynomial curve fit. However, the intent was not to produce an equation to perfectly fit the averages, as they can be compared directly without curve fitting; it was to investigate how each material property relates to the $q_{t} / q_{u}$ relationship which is best defined by a power function as observed in Figures 3 and 5.

Using the regression equations from Figures 6 through 9 , a best fit $q_{u}$ and $q_{t}$ value was generated from each material property range and paired with the respective strength value. For example, $q_{u}$ was paired with $q_{t}$ from the moisture content range $0 \%$ to $2 \%$, and $q_{u}$ was paired with $q_{t}$ from the dry unit weight range $14.9 \mathrm{kN} / \mathrm{m}^{3}$ to 15.7 $\mathrm{kN} / \mathrm{m}^{3}$. This was also done using the average values from each material property range. The split tension values were then converted to direct tension using Perras and Diederichs' (2014) recommendations for sedimentary rocks (Direct Tension $=0.70 \times$ 
Split Tension). Using the best fit and average CDI values, $q_{t}$ was plotted vs. $q_{u}$ and compared to the Florida Geomaterials equation separately.

As observed in Figures 10 and 11, using either the best fit or average values from the CDI plots (Figures 6 through 9) produced nearly identical equations to the curve-fitted Florida Geomaterials equation. Thus, the same $q_{t} / q_{u}$ relationship was found using a theoretical approach and an empirical approach. All three relationships were further investigated to determine which should be used during final side shear assessment with McVay et al (1992).

Using the available split tension data from the FDOT database, predictions of $q_{u}$ were made using the developed relationships: FL Geomaterials, CDI Average, and CDI Best Fit. The CDI predictions were made without Perras and Diederichs' (2014) reduction applied; and the Florida Geomaterials predictions were made with the reduction applied to convert direct tension to split tension $($ Split Tension $=$ Direct Tension $\div 0.70)$. The predicted $q_{u}$ values were then compared to the measured values presented in Figure 3. The frequency and cumulative frequency distributions used in the comparison are provided in Figures 12 and 13.

In all cases, the predicted values compared favorably with the measured values. The Florida Geomaterials and CDI Best Fit predictions were nearly identical and both provided better prediction than the CDI Average predictions. The Florida Geomaterials equation was determined to be the most accurate based on average compressive strength, the coefficient of variability, and the trends of the measured and predicted data over the full compressive strength range. This is more apparent in the cumulative frequency distribution (Figure 13). Therefore, the equation was used during final side 
shear assessment. From Figures 10 and 11, expressing the Florida Geomaterials equation as $q_{t}$ vs. $q_{u}$ for skin friction assessment gives

$$
q_{t}=0.612 \times q_{u}^{0.825}(\mathrm{kPa})
$$

\section{Comparative Skin Friction Analysis}

Drilled shaft MWD provides a means to measure unconfined compressive strength in real time during the shaft installation process. In addition, the developed $q_{t} / q_{u}$ relationship presented allows the foundation engineer to choose from any of the leading skin friction equations (Table 1) which are generally used in Florida drilled shaft design based on measures of compressive strength. A comparative skin friction analysis was conducted using each method at all three monitored shaft locations (Tables 4 and 5). The shaft segments included in the analysis were all fully mobilized during load testing and provided direct comparison with the predicted results from MWD.

Evident from Tables 4 and 5, several methods provided reasonable skin friction estimates compared to the load test results. Reese and O'Neill's (1987) recommended equation, developed by Horvath and Kenney (1979), provided a good conservative estimate at all three locations. Gupton and Logan's (1984) equation provided an excellent result at Kanapaha and Overland, and reasonable overestimates at Little River. This was expected as the equation was only intended for use in weaker rock found in South Florida and not higher strength limestone found in the panhandle (e.g., Little River). The McVay method, which was developed for weak, moderate, and high strength Florida limestone, used in conjunction with the Florida Geomaterials equation produced the best results. The method was in excellent agreement with the load test 
results at all three monitored locations and the average error was negligible. Furthermore, the method produced nearly identical results to Gupton and Logan's equation in weaker rock. This suggests that McVay, used with the Florida Geomaterials equation, should also be accurate in South Florida limestone formations (arenaceous geomaterial), where monitoring did not occur during this research. Consequently, McVay was chosen as the recommended equation to use with the developed drilled shaft MWD method in Florida limestone.

For convenience, the Florida Geomaterials equation was incorporated into the equation developed by McVay so skin friction could be estimated directly from $q_{u}$. The following provides the equation development:

Substituting the Florida Geomaterials equation,

$q_{t}=0.612 \times q_{u}^{0.825}$

into the skin friction equation developed by McVay et al.

$f_{s}=1 / 2 \times q_{u}^{0.5} \times q_{t}^{0.5}$

$f_{s}$ can be solved directly using only $q_{u}$,

$f_{s}=0.3912 \times q_{u}^{0.9125}$

With the final drilling equation developed to measure skin friction directly during shaft installations, additional analysis was performed to provide a better understanding of the monitoring accuracy and the variability of the results. Table 6 presents the monitoring results vs. the load test results for skin friction at each monitored location using the new equation. Again, the presented results are in portions of the shafts at each location where the skin friction was fully mobilized; thereby providing direct 
comparison of MWD to conventional methods for estimating shaft capacity. A different load test method was used at each of the sites; providing comparison with the three most conventional load test methods.

As seen in Table 6, the percent difference between the MWD and load test results revealed a relatively small range of variability, which was confirmed by conducting a bias analysis (i.e., the ratio of measured/predicted values). From the analysis, the mean and median bias were both found to be 1.00 and the coefficient of variation, CV, was less than 0.07 (Table 7 and Figure 11). The results indicate that drilled shaft construction monitoring, via MWD, is a viable solution to reducing spatial uncertainties and providing accurate measurements of compressive strength and skin friction in real time.

\section{Conclusions and Recommendations}

\section{Conclusions}

The following conclusions were drawn from this study:

- The developed monitoring method is a viable option for estimating rock strength and drilled shaft capacity in real time. This is based on compressive strength comparisons with core data obtained from traditional rock coring (Rodgers et al. 2017b) and skin friction estimations compared to three of the most widely used load testing methods (i.e., Osterberg, Statnamic, and top-down (traditional) static load testing).

- Equipment needed to monitor drilled shaft installations is often standard on new drill rigs and is commercially available for rig types without monitoring equipment 
(Rodgers et al. 2017b). This provides an easy transition to incorporate the developed method into standard drilled shaft practice.

- The developed method provides a means to quantify the quality and length of rock sockets in real time during the drilling process. This ensures the as-built foundation meets or exceeds the engineering design in real time and provides a new method of quality control for both the drilling contractor and foundation engineer.

- This research took the first steps towards reducing spatial variability concerns for structures supported by drilled shafts. Monitored drilling practices (MWD) should ultimately lead to increased resistance factors used in design. This will provide more efficient and cost effective construction practices by reducing the time of completion and cost per shaft based on reduced uncertainty (AASHTO 2009).

- It was found that there is an interdependence between the compressive and tensile strength of Florida geomaterials. In addition, new relationships were developed between material and mechanical properties. Correlations were discovered between mechanical properties (compressive and tensile strength) and material properties (dry unit weight and moisture content). This gives rise to the concept of index testing, where mechanical properties could be estimated from material properties that are easy to obtain. Core data index testing would provide a better understanding of geomaterial mechanical properties when core data is limited for sites with poor recoveries.

\section{Recommendations}

The following recommendations are based on the findings from this study: 
- Conduct more drilled shaft monitoring with load tests to further validate the developed approach.

- The concept of measuring while drilling (MWD) should be adapted to more geotechnical engineering applications.

- MWD should be developed for Auger Cast in Place (ACIP) piles where visual inspection of the drilled cuttings does not occur. This would provide reliability for a deep foundation type that is steadily gaining popularity for its ease of construction and efficiency.

- MWD should also be used as a site investigation tool on SPT rigs to provide additional data used for geotechnical engineering design purposes. This would provide continuous measurements of rock strength and a means to quantify the quality of the coring procedure. Incorporating the developed method onto a SPT rig would provide continuous measurements, similar to a CPT, with the ability to penetrate through layers of rock which terminates a CPT. The method should be used while advancing the hole with a roller bit and during coring with a core barrel.

- The concept of index testing should be explored for dry unit weight, moisture content, porosity, and carbonate content. This will provide an estimated reference of strength for sites with poor recoveries.

- Finally, this research specifically focused on reducing the uncertainty of drilled shafts socketed into Florida limestone, as a very high degree of variability is typically encountered throughout the state. However, the concept of monitoring drilled shaft installations could easily be translated to any rock type when coupled with a load testing program. This is achieved through measurements of specific energy 
recorded during the excavation of load tested shafts. Since measurements of specific energy (Teale 1965) only rely on drilling parameters torque, crowd, rotational speed, penetration rate and bit diameter, and not the Florida-specific correlations developed in this research, an acceptable limit of required specific energy could be established based on the results of the load test. This would provide a minimum requirement of specific energy that must be achieved for each production shaft when drilling into layers of rock, IGM, or OC Clay. As a result, the insight gained from load testing would be translated directly to the production shafts and ensure the as-built foundations meet or exceed the expectations of the engineering design. This would alleviate concerns due to uncertainty and ultimately lead to the use of higher LRFD resistance factors, which reduces the overall construction costs associated with drilled shafts.

\section{Acknowledgments}

The assistance of the FDOT's State Materials Office as well as the district and central Geotechnical Engineers is greatly appreciated. The authors would like to thank all participants that assisted with the field research, Jean Lutz: Michel Lariau, RS\&H: Tony Manos and Tim Brown; Case Atlantic: J.R. "Hawk" Hawkins and Chris Patrick; Archer Western: Heath Bunn, Patricio Degaudenzi, Paul Harrell, Joshua Bachman, Jimmy Graham, and Mike Close; Eisman \& Russo, Inc.: Bill Brown, Joe Delucia, Al Moyle, John Kemp, and Tony Mahfoud; Moretrench: Jeff Lewman, Kris Strenberg, Tom Robertson, and Harley; Reliable Constructors, Inc.: Roger Rehfeldt, Ray Rehfeldt, Graylan "Spyder" Hodge, Craig Eggert, Austin West, Arthur Wright, and Reagen Norris; Loadtest: Bill Ryan, Roberto Singh, Aditya Ayithi, Denton Kort, Dany Romero, and 
Adam Scherer; AFT: Don Robertson, Michael Muchard, Nicholas Pigott, and Evan Clay; Universal Engineering: Jeff Pruett, Adam Kirk, Chris Shaw, and Josh Adams; FDOT: Bruce Swidarski, Todd Britton, Kyle Sheppard, Travis "Dalton" Stevens, Jimmy Williams, Michael Horst, Jesse Sutton, Chandra Samakur, John Hardy, Jamie Rogers, Enondrus Phillips, Patrick Munyon, Jason Thomas, Sam Weede, Gabriel Camposagrado, Chuck Crews, Bo Cumbo, and David Gomez; University of Florida: Richard Booze, Sudheesh Thiyyakkandi, Scott Wasman, Mike Faraone, Khiem Tran, Cary Peterson, and Anand Patil. Without your assistance, this research would not have been possible.

Funding: This work was supported by the Florida Department of Transportation through research contract No. BDV 31977 20. The opinions, findings and conclusions expressed in this publication are those of the author(s) and not necessarily those of the Florida Department of Transportation or the U.S. Department of Transportation.

\section{References}

AASHTO. 2009. LRFD Bridge Design Specifications, 4th Ed (2009 Interim Revisions). American Association of State Highway and Transportation Officials. Washington, DC.

Anoglu, N., Girgin Z., and Anoglu, E. 2006. Evaluation of Ratio between Splitting Tensile Strength and Compressive Strength for Concrete up to $120 \mathrm{MPa}$ and its Application in Strength Criterion. ACI Materials Journal. 103-M03.

Baud, P., Wong T., and Zhu, W. 2014. Effects of porosity and crack density on the compressive strength of rocks. International Journal of Rock Mechanics and Mining Sciences. 67:202-211. 
Brown, D., Turner J., and Castelli, R. 2010. Drilled Shafts: Construction Procedures and LRFD Design Methods. Publication No. FHWA-NHI-10-016, Federal Highway Administration. Washington, DC.

Carter, J., and Kulhawy, F. 1987. Analysis and Design of Foundations Socketed into Rock. Research Report 1493-4, Geotechnical Engineering Group. Ithaca; NY: Cornell University.

Chen, X., Wu S., and Zhou, J. 2013. Influence of porosity on compressive and tensile strength of mortar cement. Construction and Building Materials. 40:869-874.

Chung, J., Ko J., Klammler H., McVay M., and Lai, P. 2012. A numerical and experimental study of bearing stiffness of drilled shafts socketed into heterogeneous rock. Computers and Structures. Vol. 90-91:145-152.

Claesson, J., and Bohloli, B. 2002. Brazilian test: Stress field and tensile strength of anisotropic rocks using an analytical solution. International Journal of Rock Mechanics and Mining Sciences. 39(8):991-1004.

Florida Department of Transportation (FDOT). 2015. Soils and Foundation Handbook. Florida Department of Transportation, State Materials Office. Gainesville; FL.

Gupton, C., and Logan, T. 1984. Design Guidelines for Drilled Shafts in Weak Rocks of South Florida. Proceedings of the South Florida Annual ASCE Meeting. ASCE. Horvath, R., and Kenney, T. 1979. Shaft Resistance of Rock-Socketed Drilled Piers. Symposium on Deep Foundations, ASCE National Convention. Atlanta; GA. 182214.

Johnston, I. 1985. Strength of Intact Geomechanical Materials. ASCE Journal of Geotechnical Engineering. 111:730-749. 
Lambe, T.W., and Whitman, R.V. 1969. Soil Mechanics. John Wiley \& Sons, New York. McVay, M., Townsend, F., and Williams, R. 1992. Design of Socketed Drilled Shafts in Limestone. ASCE Journal of Geotechnical Engineering. 118:10:1626-1637.

Perras, M., and Diederichs, M. 2014. A Review of the Tensile Strength of Rock: Concepts and Testing. Geotechnical and Geological Engineering. 32:525. doi:10.1007/s10706/s10706-014-9732-0.

Rajabzadeh, M., Moosavinasab, Z., and Rakhshanderhroo, G. 2012. Effects of Rock Classes and Porosity on the Relation between Uniaxial Compressive Strength and Some Rock Properties for Carbonate Rocks. Rock Mechanics and Rock Engineering. 45(1).

Ramos, H., Antorena, J., and McDaniel, G. 1994. Correlations between the Standard Penetration Testing (SPT) and the Measured Shear Strength of Florida Natural Rock. Proceedings from FHWA International Conference on Design and Construction of Deep Foundations. Orlando; FL. 699-711.

Reese, L., and O'Neill, M. 1987. Drilled Shafts: Construction Procedures and Design Methods, Design Manual. US Department of Transportation, Federal Highway Administration. McLean; VA.

Reynolds, R., and Kaderabek, T. 1980. Miami Limestone Foundation Design and Construction. ASCE. New York; NY.

Rodgers, M., McVay, M., Ferraro, C., Horhota, D., Tibbetts, C., and Crawford, S. 2017a. Measuring Rock Strength While Drilling Shafts Socketed Into Florida Limestone. ASCE Journal of Geotechnical and Geoenvironmental Engineering.

doi.org/10.1061/(ASCE)GT.1943-5606.0001847 
Rodgers, M., McVay, M., Horhota, D., and Hernando, J. 2017b. Assessment of Rock Strength from Measuring While Drilling Shafts in Florida Limestone. Canadian Geotechnical Journal. doi.org/10.1139/cgj-2017-0321

Rowe, R., and Armitage, H. 1987. A Design Method for Drilled Piers in Soft Rock. Canadian Geotechnical Journal. 24(1):126-142.

Teale, R. 1965. The Concept of Specific Energy in Rock Drilling. International Journal of Rock Mechanics and Mining Sciences. 2:57-73.

Vasarhelyi, B., and Van, P. 2006. Influence of water content on the strength of rock. Engineering Geology. 84(1):70-74.

Williams, A., Johnston, I., and Donald, I. 1980. The Design of Socketed Piles in Weak Rock. Proc. Int. Conf. on Struct. Foundations in Rock, (Netherlands). 327-347.

Wong, L., Maruvanchery, V., and Liu, G. 2016. Water effects on rock strength and stiffness degradation. Acta Geotechinca. 11(4):713-737.

Yilmaz, I. 2010. Influence of water content on the strength and deformability of gypsum. International Journal of Rock Mechanics and Mining Sciences. 47(2):342-347.

\section{Figure Captions}

Figure 1. Drilled shaft load transfer diagram.

Figure 2. Little River $q_{t} / q_{u}$ analysis using all boring locations with outliers removed.

Figure 3. $q_{t} / q_{u}$ vs. $q_{u}$ relationship for various geomaterials using Johnston's criteria.

Figure 4. Frequency distribution of Florida limestone compressive strengths.

Figure 5. Comparison of $q_{t} / q_{u}$ vs. $q_{u}$ curves with the new Florida geomaterials curve.

Figure 6. Core data index plot, unconfined compressive strength vs. moisture content.

Figure 7. Core data index plot, splitting tensile strength vs. moisture content. 
Figure 8. Core data index plot, dry unit weight vs. unconfined compressive strength.

Figure 9. Core data index plot, dry unit weight vs. splitting tensile strength.

Figure 10. Comparing the CDI Best Fit values $q_{t}$ vs. $q_{u}$ relationship with the FL Geomaterials equation.

Figure 11. Comparing the CDI Average values $q_{t}$ vs. $q_{u}$ relationship with the FL Geomaterials equation.

Figure 12. Frequency distribution comparing predicted $q_{u}$ values with measured $q_{u}$ values.

Figure 13. Cumulative Frequency distribution comparing predicted $q_{u}$ values with measured $q_{u}$ values.

Figure 14. Unit side shear bias analysis Measured/Predicted (Load Test/Monitoring). 


\section{Tables}

Table 1. Drilled shaft design skin friction equations.

\begin{tabular}{|c|c|c|}
\hline Method & Author & Design Methodology \\
\hline 1 & McVay et al. (1992) & $\mathrm{f}_{\mathrm{s}}=1 / 2 \times \sqrt{\mathrm{q}_{\mathrm{u}}} \times \sqrt{\mathrm{q}_{\mathrm{t}}}(\mathrm{kPa})$ \\
\hline 2 & Reese and O'Neill (1987) & $\mathrm{f}_{\mathrm{s}}=0.15 \times \mathrm{q}_{\mathrm{u}}(\mathrm{kPa})$ \\
\hline 3 & Horvath and Kenney (1979) & $\mathrm{f}_{\mathrm{s}}=6.56 \times \sqrt{\mathrm{qu}_{\mathrm{u}}}(\mathrm{kPa})$ \\
\hline 4 & Williams et al. (1980) & $\mathrm{f}_{\mathrm{s}}=0.3453 \times \mathrm{q}_{\mathrm{u}}^{0.367}(\mathrm{kPa})$ \\
\hline 5 & Reynolds and Kaderabek (1980) & $\mathrm{f}_{\mathrm{s}}=0.3 \times \mathrm{q}_{\mathrm{u}}(\mathrm{kPa})$ \\
\hline 6 & Gupton and Logan (1984) & $\mathrm{f}_{\mathrm{s}}=0.2 \times \mathrm{q}_{\mathrm{u}}(\mathrm{kPa})$ \\
\hline 7 & Carter and Kulhawy (1987) & $\mathrm{f}_{\mathrm{s}}=6.17 \times \sqrt{\mathrm{qu}_{\mathrm{u}}}(\mathrm{kPa})$ \\
\hline 8 & Ramos et al. (1994) & $\begin{array}{r}\mathrm{f}_{\mathrm{s}}=0.5 \times \mathrm{q}_{\mathrm{u}}(<1,724 \mathrm{kPa}) \\
\mathrm{f}_{\mathrm{s}}=0.12 \times \mathrm{q}_{\mathrm{u}}(>1,724 \mathrm{kPa})\end{array}$ \\
\hline 9 & Rowe and Armitage (1987) & $\mathrm{f}_{\mathrm{s}}=14.19 \times \sqrt{\mathrm{qu}_{\mathrm{u}}}(\mathrm{kPa})$ clean sockets \\
\hline 10 & Rowe and Armitage (1987) & $\mathrm{f}_{\mathrm{s}}=18.98 \times \sqrt{\mathrm{qu}_{\mathrm{u}}}(\mathrm{kPa})$ rough sockets \\
\hline
\end{tabular}

Table 2. Preliminary skin friction analysis at Little River.

\begin{tabular}{lcrr}
\hline \multicolumn{4}{c}{ Little River } \\
& Skin Friction, $\mathrm{f}_{\mathrm{s}}(\mathrm{kPa})$ & \\
\hline Section & Load Test & Monitoring & Error \\
SG7 to SG6 & 1010 & 996 & $-1.42 \%$ \\
SG6 to O-cell & 986 & 1096 & $11.17 \%$ \\
O-cell to SG5 & 1025 & 977 & $-4.67 \%$ \\
SG5 to SG4 & 651 & 666 & $2.21 \%$ \\
Average & 919 & 934 & $1.82 \%$ \\
\hline
\end{tabular}


Table 3. Core data from Little River indicating dissimilar materials.

\begin{tabular}{crrrrrrr}
\hline $\begin{array}{c}\text { Boring/ } \\
\text { Shaft-Core }\end{array}$ & $\begin{array}{c}\text { Sample } \\
\text { No. }\end{array}$ & $\begin{array}{c}\text { Test } \\
\text { Type }\end{array}$ & $\begin{array}{c}\text { Moisture } \\
(\%)\end{array}$ & $\begin{array}{c}\text { Dry Unit Weight } \\
\left(\mathrm{kN} / \mathrm{m}^{3}\right)\end{array}$ & $\begin{array}{c}\text { Max Load } \\
(\mathrm{kN})\end{array}$ & $\begin{array}{c}\mathrm{q}_{\mathrm{t}} \\
(\mathrm{kPa})\end{array}$ & $\begin{array}{c}\mathrm{q}_{\mathrm{u}} \\
(\mathrm{kPa})\end{array}$ \\
\hline $2 / 1-2$ & 1 & $\mathrm{~T}$ & 59.8 & 9.9 & 0.2 & 44.8 & \\
& 2 & $\mathrm{U}$ & 58.2 & 10.2 & 0.6 & & 262.7 \\
& 3 & $\mathrm{~T}$ & 60.1 & 9.9 & 0.3 & 55.8 & \\
& 4 & $\mathrm{U}$ & 69.0 & 9.4 & 0.3 & & 116.5 \\
& 5 & $\mathrm{~T}$ & 3.2 & 24.5 & 42.3 & 6723.8 & \\
& 6 & $\mathrm{~T}$ & 3.8 & 21.2 & 14.1 & 2256.7 & \\
& 7 & $\mathrm{U}$ & 5.1 & 21.1 & 23.7 & & 7700.8 \\
& 8 & $\mathrm{~T}$ & 7.6 & 20.7 & 9.2 & 1503.7 & \\
& 9 & $\mathrm{~T}$ & 4.8 & 23.5 & 4.6 & 739.8 & \\
& 10 & $\mathrm{~T}$ & 61.3 & 9.9 & 0.2 & 27.6 & \\
& 11 & $\mathrm{~T}$ & 28.8 & 14.4 & 0.2 & 35.9 & \\
\hline
\end{tabular}

Table 4. Skin friction comparative analysis using methods 1 through 5.

\begin{tabular}{llrrrrrr}
\hline \multirow{2}{*}{ Location } & \multicolumn{7}{c}{ Unit Side Shear Method, $\mathrm{f}_{\mathrm{s}}(\mathrm{kPa})$} \\
& Section & Load Test & $(1)$ & $(2)$ & $(3)$ & $(4)$ & $(5)$ \\
\hline \multirow{5}{*}{ Little River } & SG8 to SG7 & 474 & 534 & 425 & 312 & 550 & 849 \\
& SG7 to SG6 & 1010 & 942 & 805 & 411 & 670 & 1609 \\
& SG6 to O-cell & 986 & 1058 & 891 & 469 & 748 & 1781 \\
& O-cell to SG5 & 1025 & 932 & 789 & 421 & 687 & 1578 \\
& SG5 to SG4 & 651 & 668 & 537 & 365 & 623 & 1074 \\
\hline \multirow{5}{*}{ Kanapaha } & TS SG1 to SG2 & 384 & 413 & 313 & 288 & 526 & 626 \\
& TS SG2 to SG3 & 394 & 392 & 295 & 279 & 515 & 591 \\
& TS SG4 to Base & 233 & 234 & 169 & 210 & 417 & 337 \\
& ES SG1 to SG2 & 113 & 113 & 78 & 123 & 261 & 156 \\
\hline Overland & Segment 2 & 99 & 91 & 60 & 123 & 280 & 120 \\
\hline \multicolumn{2}{l}{ Average Percent Error } & N/A & $0.6 \%$ & $-22.2 \%$ & $-27.9 \%$ & $38.3 \%$ & $55.6 \%$ \\
\hline
\end{tabular}


Table 5. Skin friction comparative analysis using methods 6 through 10 .

\begin{tabular}{llrrrrrr}
\hline & & \multicolumn{7}{c}{ Unit Side Shear Method, $\mathrm{f}_{\mathrm{s}}(\mathrm{kPa})$} \\
Location & Section & Load Test & $(6)$ & $(7)$ & $(8)$ & $(9)$ & $(10)$ \\
\hline \multirow{5}{*}{ Little River } & SG8 to SG7 & 474 & 566 & 293 & 501 & 674 & 693 \\
& SG7 to SG6 & 1010 & 1073 & 386 & 781 & 889 & 1190 \\
& SG6 to O-cell & 986 & 1187 & 441 & 733 & 1015 & 1358 \\
& O-cell to SG5 & 1025 & 1052 & 396 & 730 & 910 & 1218 \\
& SG5 to SG4 & 651 & 716 & 343 & 606 & 790 & 1057 \\
\hline \multirow{5}{*}{ Kanapaha } & TS SG1 to SG2 & 384 & 417 & 271 & 414 & 623 & 833 \\
& TS SG2 to SG3 & 394 & 394 & 263 & 389 & 604 & 809 \\
& TS SG4 to Base & 233 & 225 & 197 & 426 & 454 & 607 \\
\hline Overland & ES SG1 to SG2 & 113 & 104 & 116 & 226 & 266 & 356 \\
\hline \multicolumn{2}{l}{ Average Pegment 2 } & 99 & 80 & 116 & 200 & 266 & 356 \\
\hline
\end{tabular}

Table 6. Skin friction comparative analysis summary using Equation 11.

\begin{tabular}{lllrrrr}
\hline $\begin{array}{c}\text { Location/ } \\
\text { Reference) }\end{array}$ & \multicolumn{1}{c}{ Section } & Test Type & $\begin{array}{r}\text { Thickness } \\
(\mathrm{m})\end{array}$ & $\begin{array}{r}\text { Measured } \\
(\mathrm{kPa})\end{array}$ & $\begin{array}{r}\text { Predicted } \\
(\mathrm{kPa})\end{array}$ & \% Difference \\
\hline Little River (LR-1) & SG8 to SG7 & Osterberg & 3.05 & 474 & 534 & $12.63 \%$ \\
Little River (LR-2) & SG7 to SG6 & Osterberg & 1.52 & 1010 & 942 & $-6.78 \%$ \\
Little River (LR-3) & SG6 to O-cell & Osterberg & 1.68 & 986 & 1058 & $7.23 \%$ \\
Little River (LR-4) & O-cell to SG5 & Osterberg & 1.07 & 1025 & 932 & $-9.07 \%$ \\
Little River (LR-5) & SG5 to SG4 & Osterberg & 1.52 & 651 & 668 & $2.57 \%$ \\
\hline Kanapaha (K-1) & SG1 to SG2 & Static & 0.91 & 384 & 413 & $7.48 \%$ \\
Kanapaha (K-2) & SG2 to SG3 & Static & 0.91 & 394 & 392 & $-0.49 \%$ \\
Kanapaha (K-3) & SG4 to Base & Static & 0.61 & 233 & 234 & $0.41 \%$ \\
Kanapaha (K-4) & East Shaft & Static & 1.52 & 113 & 113 & $0.00 \%$ \\
\hline Overland (O-1) & Segment 2 & Statnamic & 1.52 & 99 & 91 & $-7.77 \%$ \\
\hline Average & All & All & 1.43 & 537 & 538 & $0.62 \%$ \\
\hline
\end{tabular}

Table 7. Unit side shear bias analysis summary of statistics.

\begin{tabular}{lr}
\hline Statistics & Bias \\
\hline Average & 1.00 \\
Median & 1.00 \\
Std. Dev. & 0.068 \\
CV & 0.068 \\
Count & 10 \\
\hline
\end{tabular}




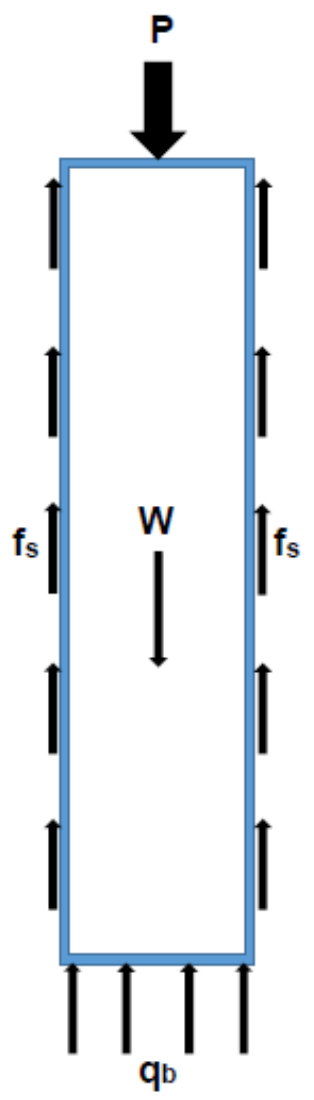

Figure 1. Drilled shaft load transfer diagram. 


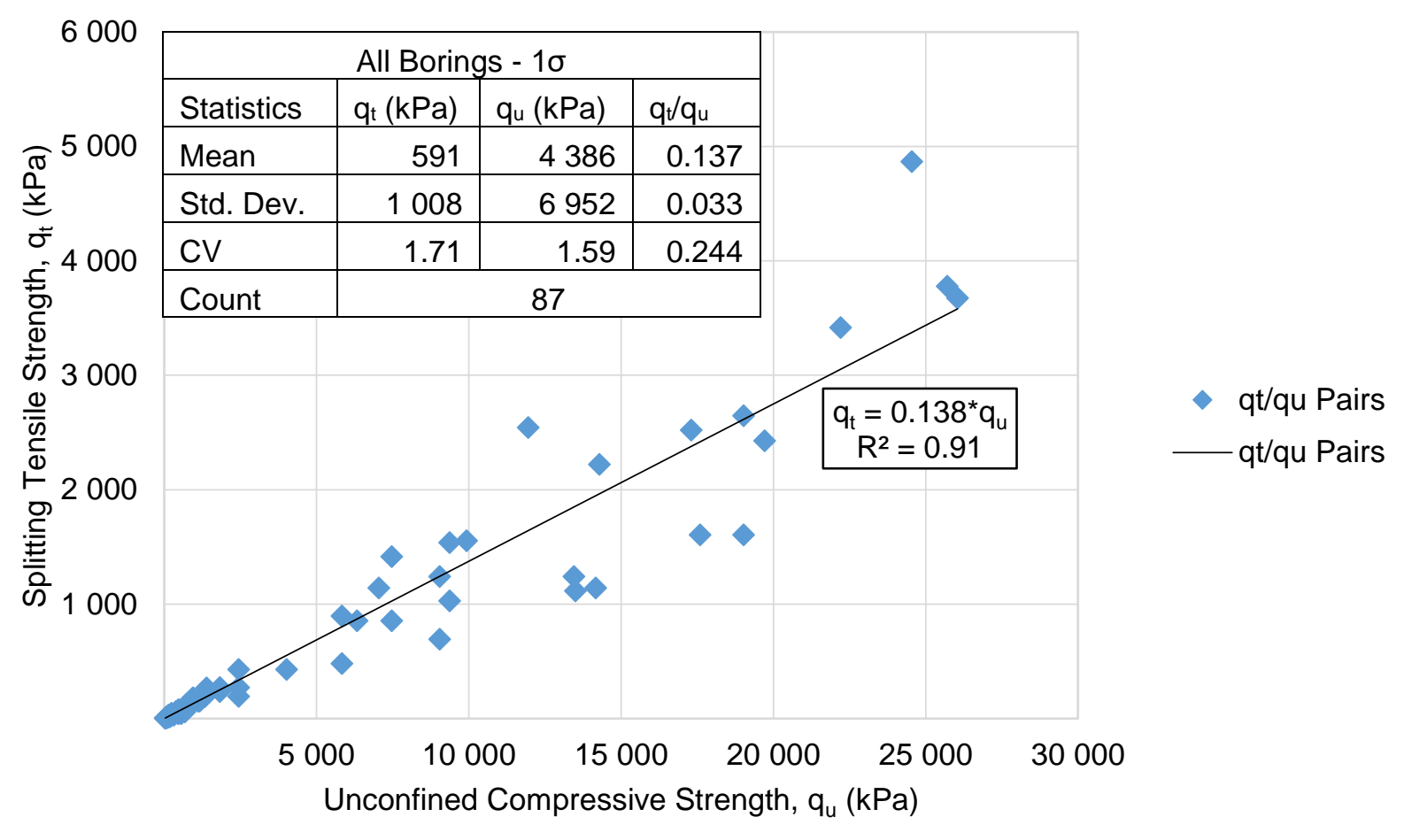

Figure 2. Little River $q_{t} / q_{u}$ analysis using all boring locations with outliers removed. 


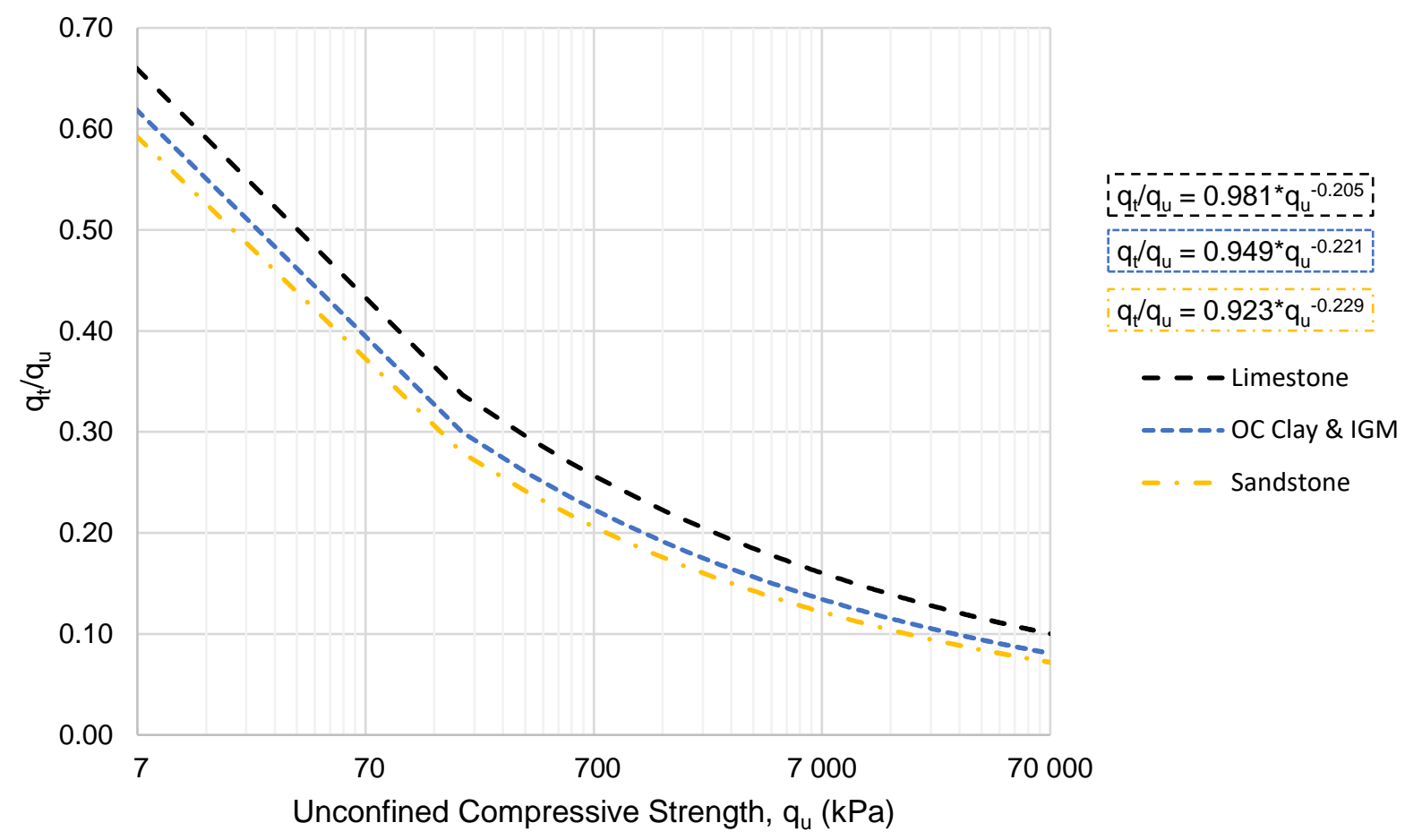

Figure 3. $q_{t} / q_{u}$ vs. $q_{u}$ relationship for various geomaterials using Johnston's criteria. 


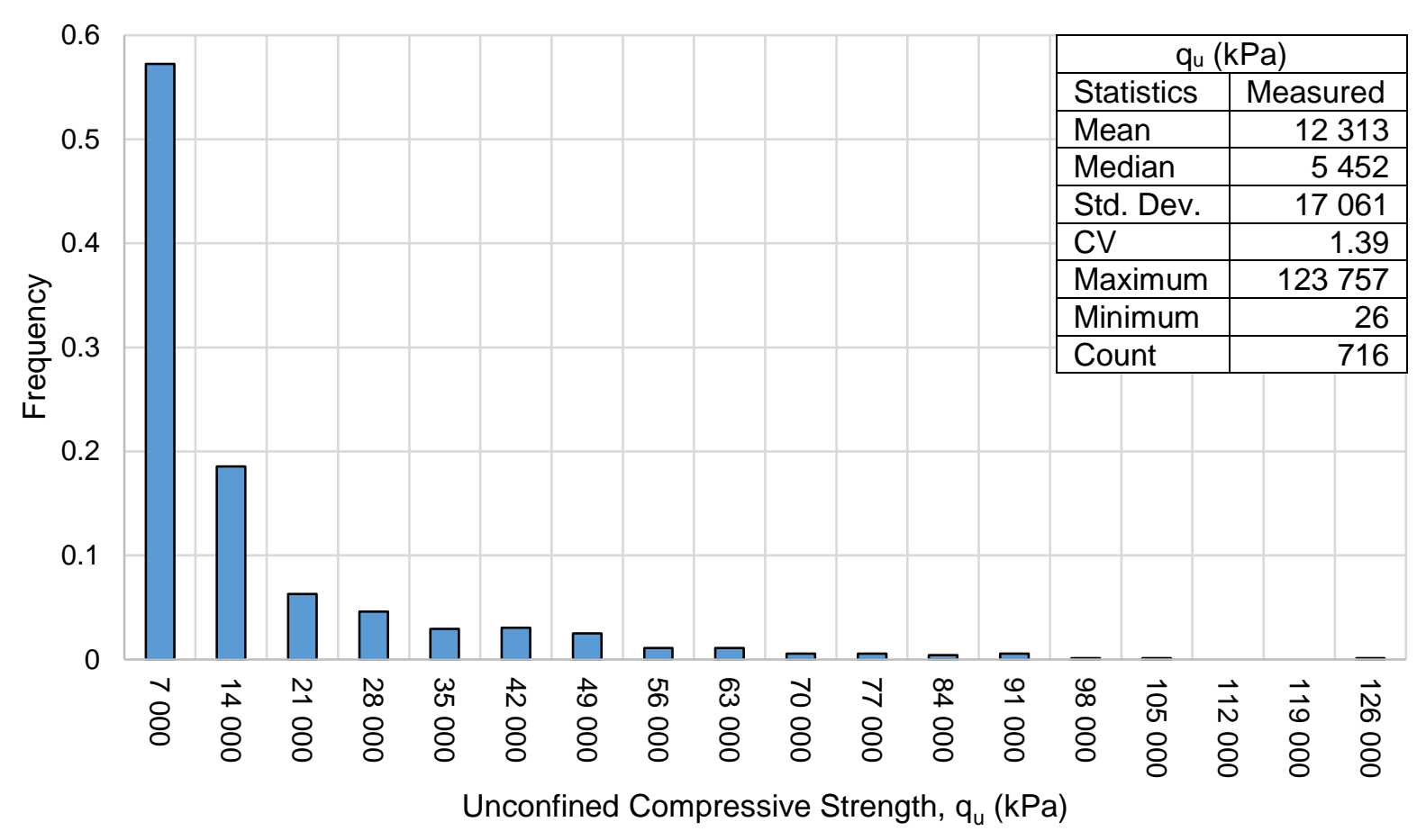

Figure 4. Frequency distribution of Florida limestone compressive strengths. 


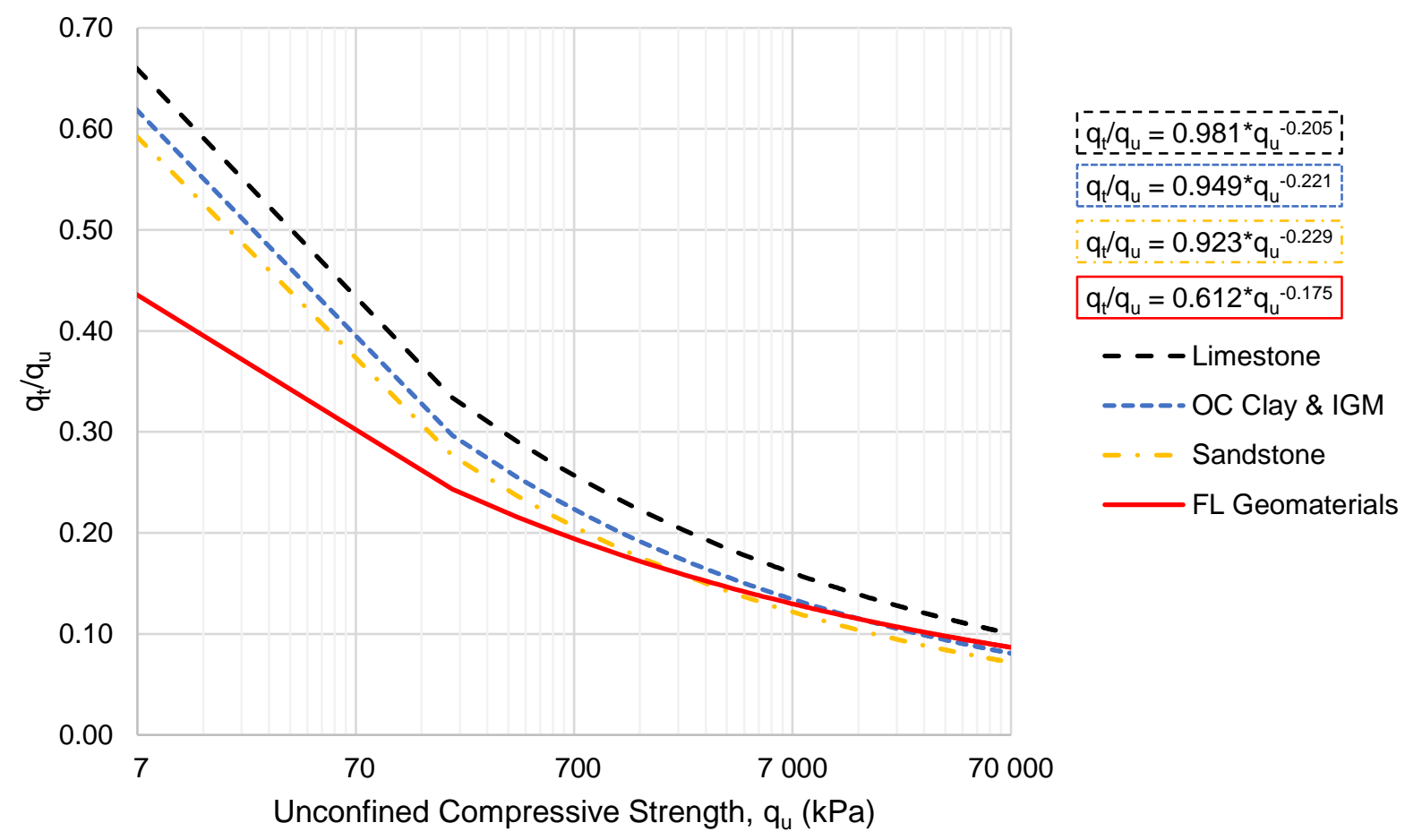

Figure 5. Comparison of $q_{t} / q_{u}$ vs. $q_{u}$ curves with the new Florida geomaterials curve. 


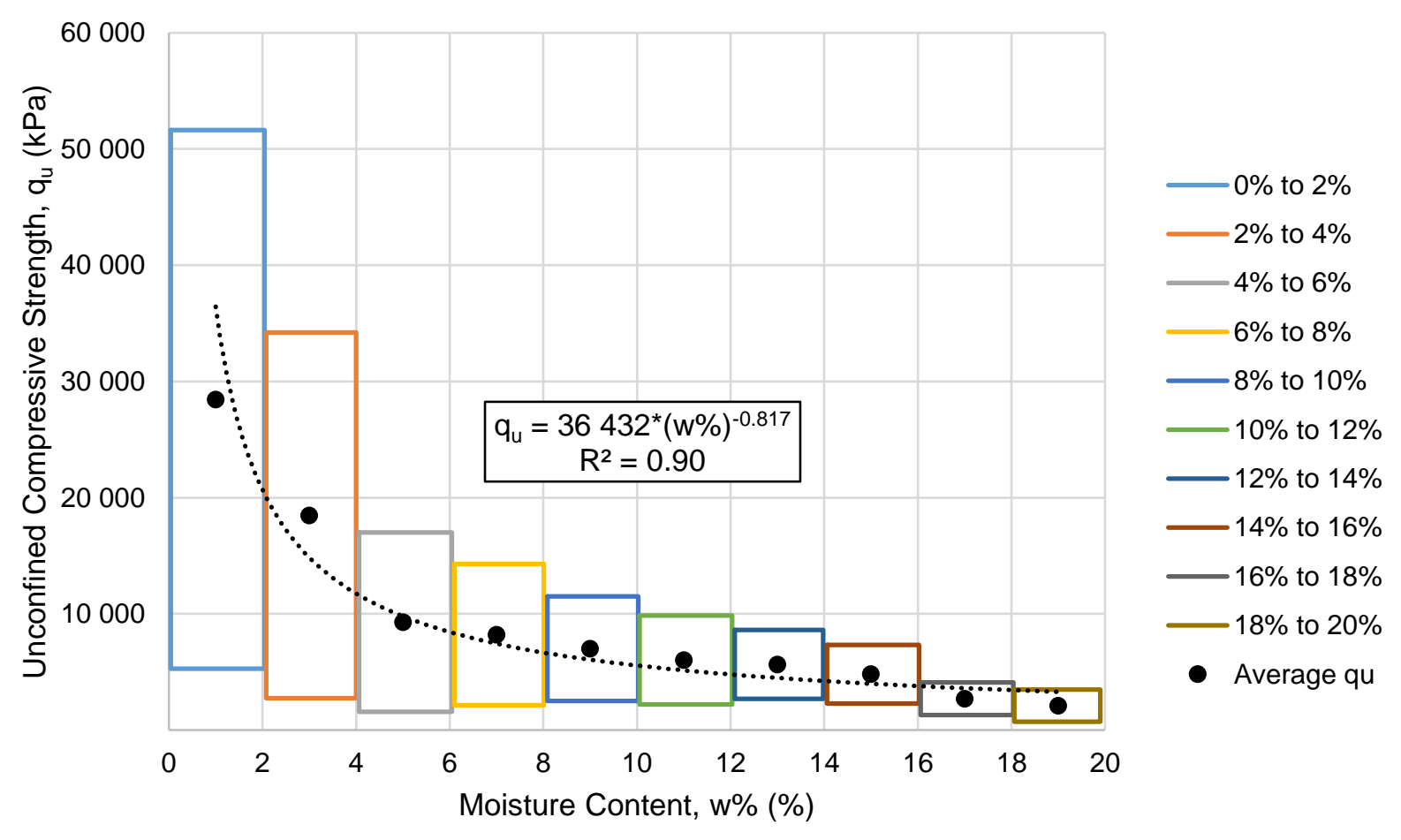

Figure 6. Core data index plot, unconfined compressive strength vs. moisture content. 


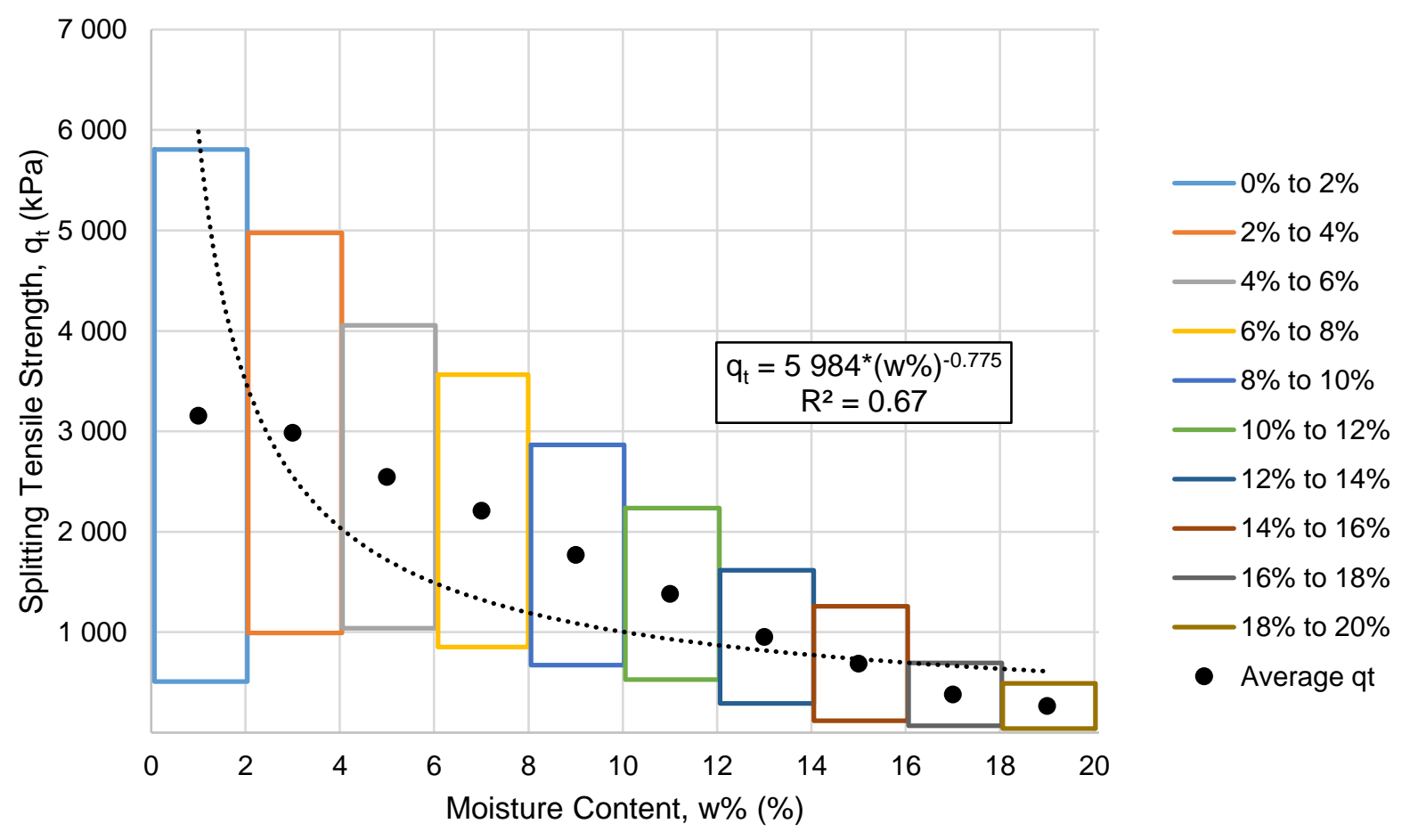

Figure 7. Core data index plot, splitting tensile strength vs. moisture content. 


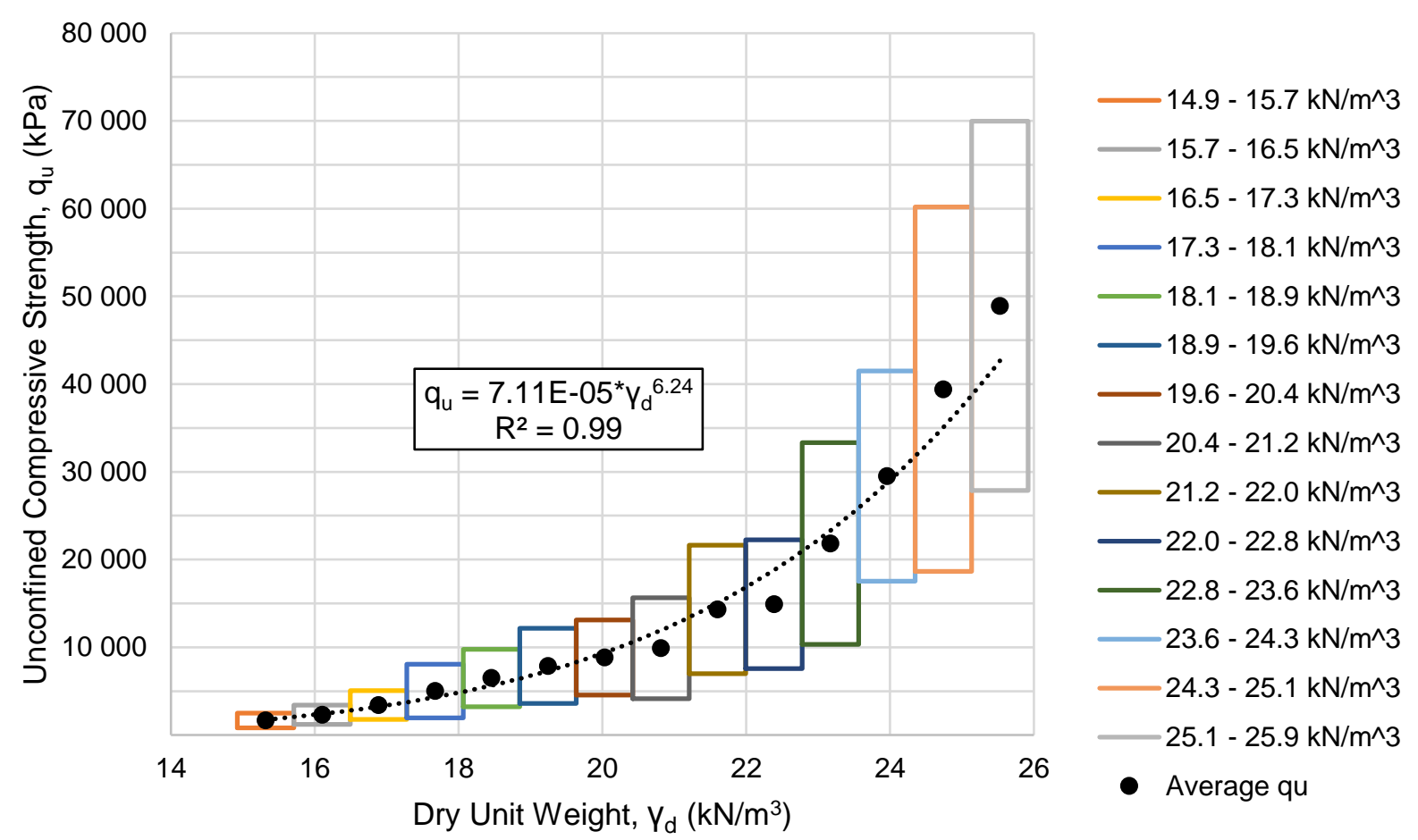

Figure 8. Core data index plot, unconfined compressive strength vs. dry unit weight. 


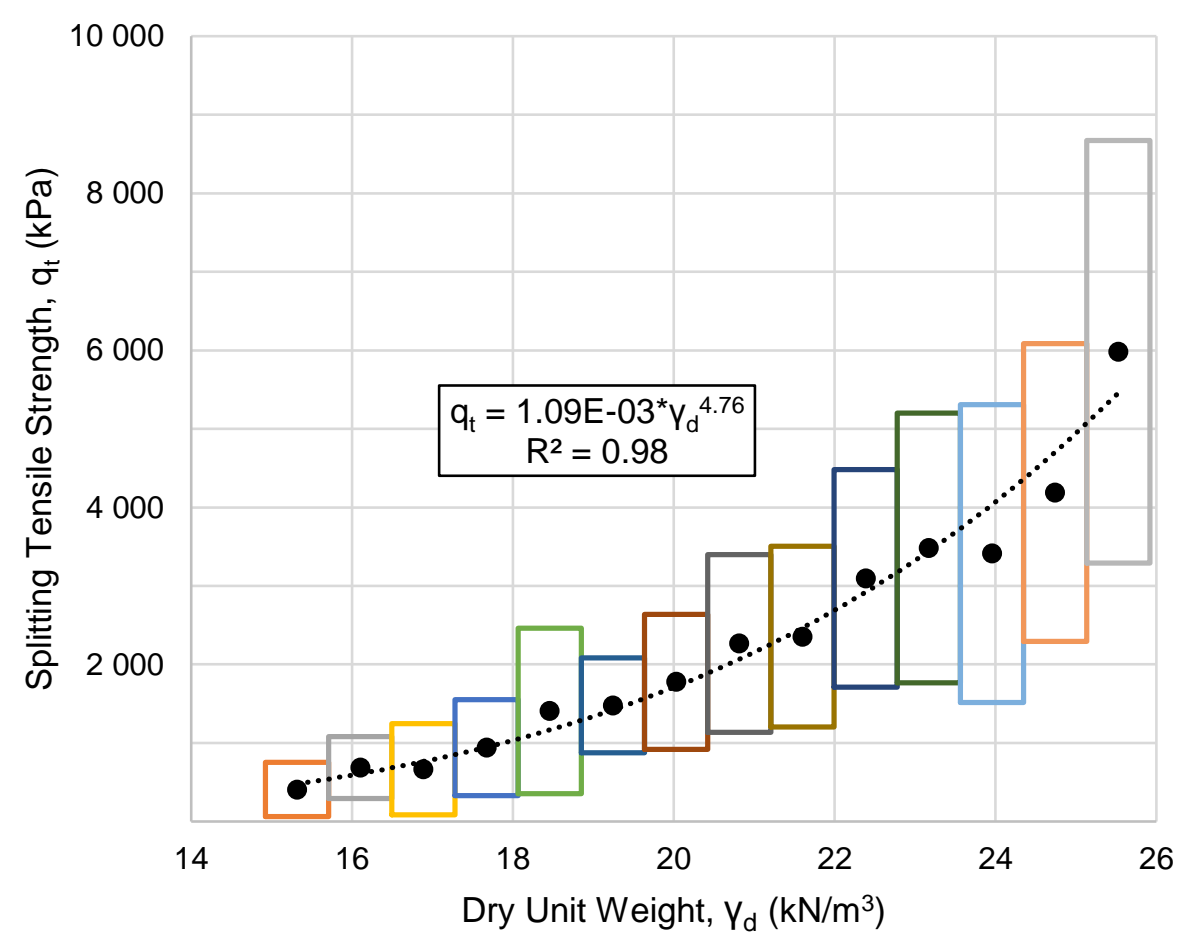

$14.9-15.7 \mathrm{kN} / \mathrm{m}^{\wedge} 3$

$15.7-16.5 \mathrm{kN} / \mathrm{m}^{\wedge} 3$

$16.5-17.3 \mathrm{kN} / \mathrm{m}^{\wedge} 3$

$17.3-18.1 \mathrm{kN} / \mathrm{m}^{\wedge} 3$

$-18.1-18.9 \mathrm{kN} / \mathrm{m}^{\wedge} 3$

$18.9-19.6 \mathrm{kN} / \mathrm{m}^{\wedge} 3$

$19.6-20.4 \mathrm{kN} / \mathrm{m}^{\wedge} 3$

$20.4-21.2 \mathrm{kN} / \mathrm{m}^{\wedge} 3$

$21.2-22.0 \mathrm{kN} / \mathrm{m}^{\wedge} 3$

$22.0-22.8 \mathrm{kN} / \mathrm{m}^{\wedge} 3$

$22.8-23.6 \mathrm{kN} / \mathrm{m}^{\wedge} 3$

$23.6-24.3 \mathrm{kN} / \mathrm{m}^{\wedge} 3$

$24.3-25.1 \mathrm{kN} / \mathrm{m}^{\wedge} 3$

$25.1-25.9 \mathrm{kN} / \mathrm{m}^{\wedge} 3$

- Average qt

Figure 9. Core data index plot, splitting tensile strength vs. dry unit weight. 


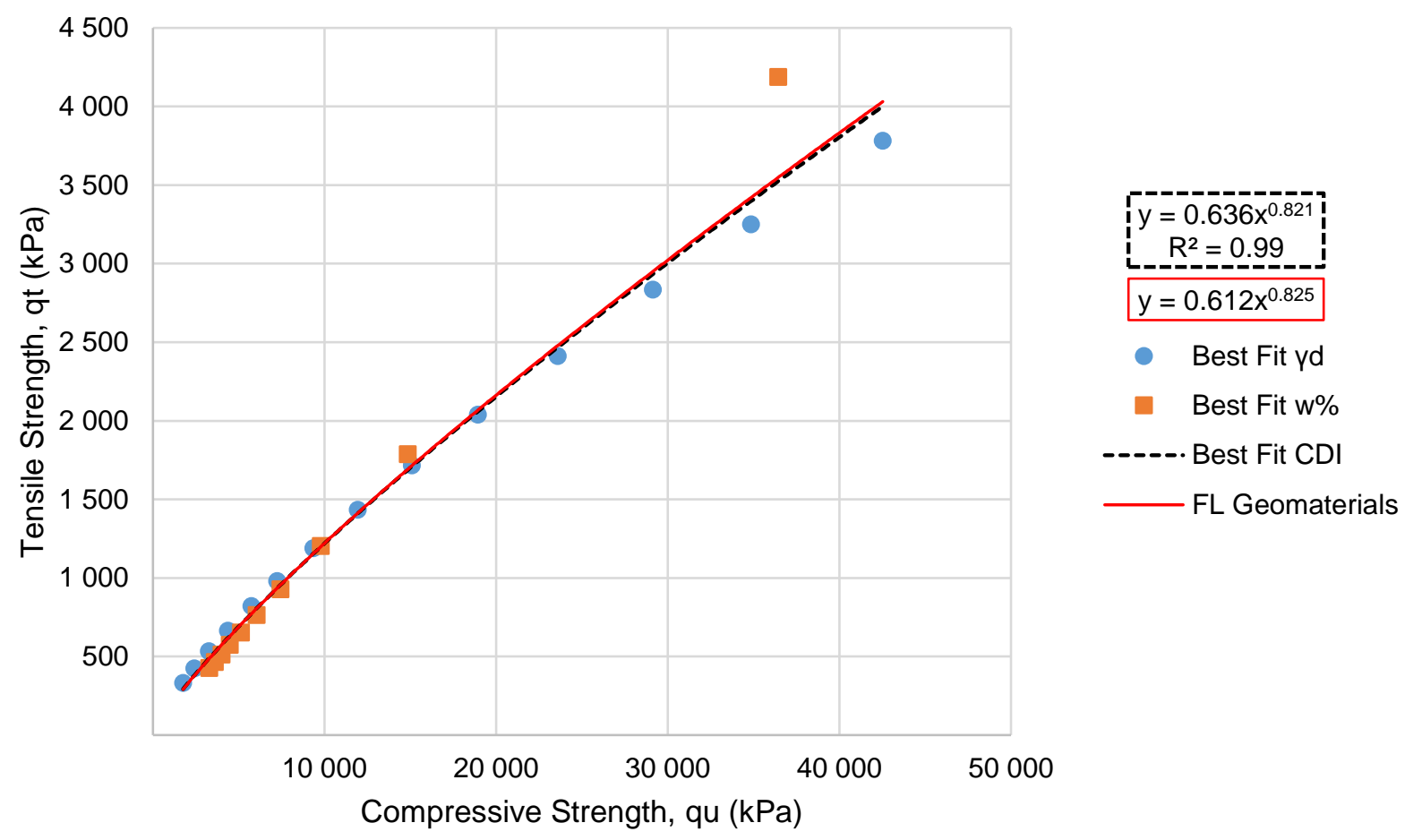

Figure 10. Comparing the CDI Best Fit values $q_{t}$ vs. $q_{u}$ relationship with the FL Geomaterials equation. 


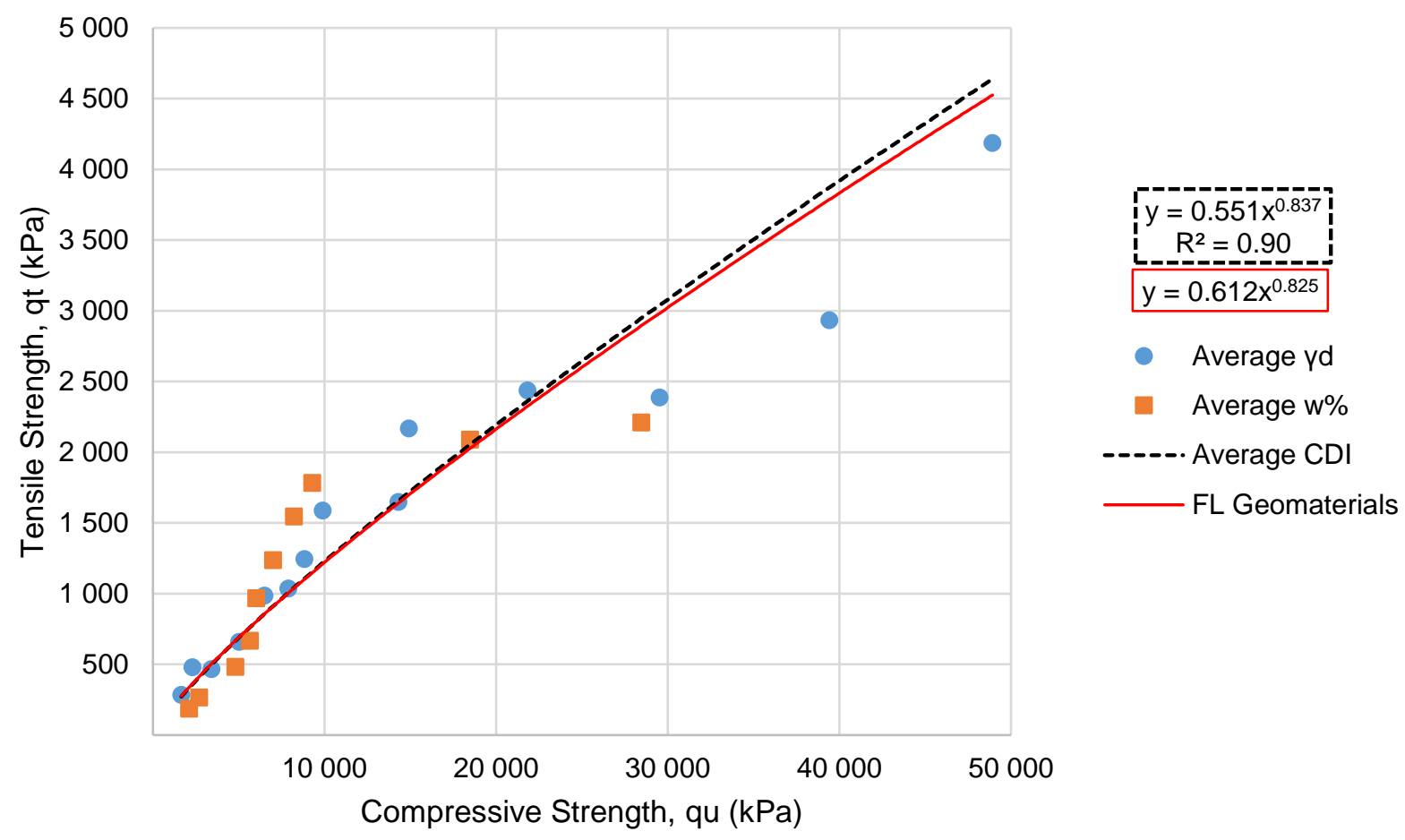

Figure 11. Comparing the CDI Average values $q_{t}$ vs. $q_{u}$ relationship with the FL Geomaterials equation. 


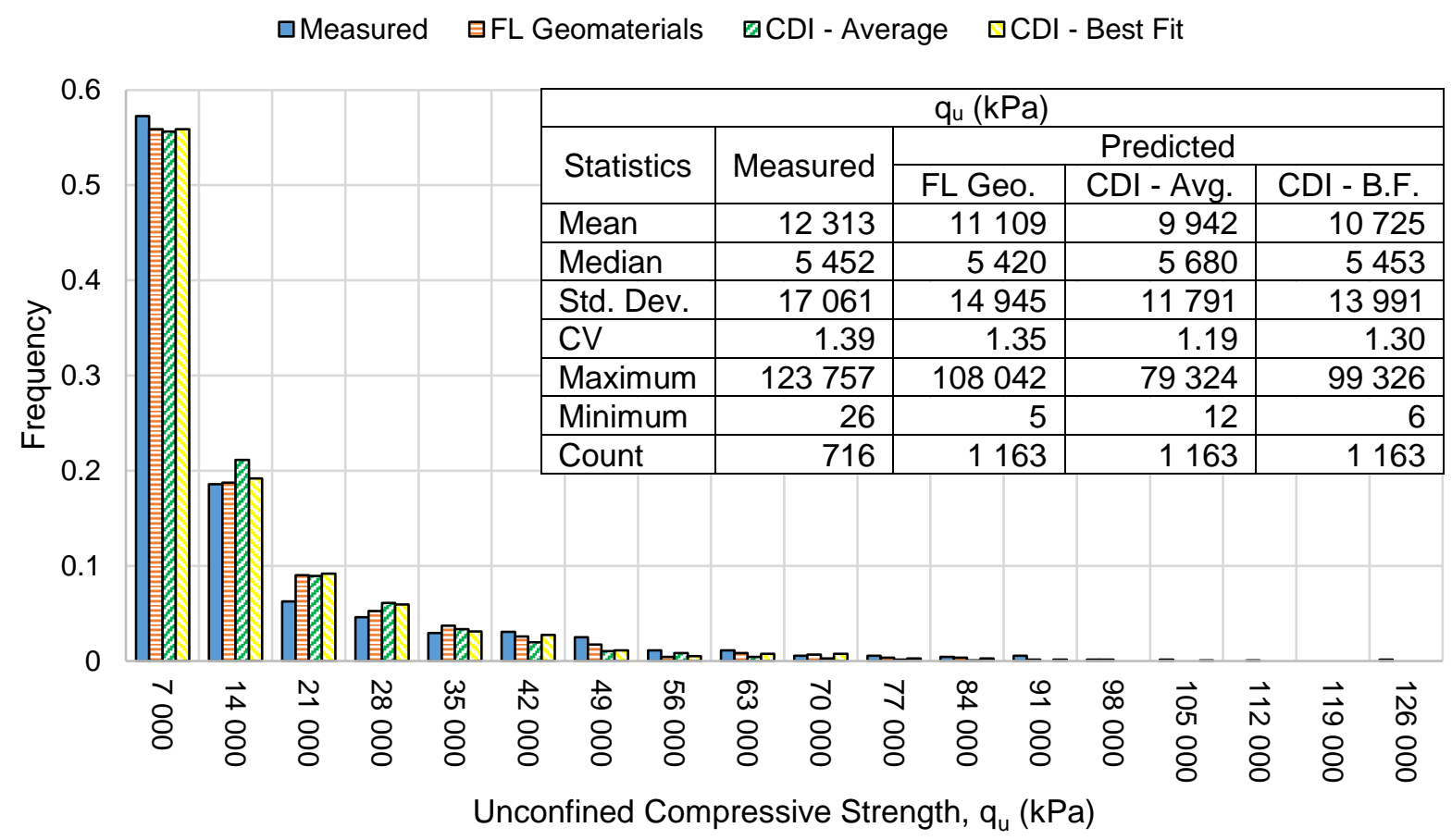

Figure 12. Frequency distribution comparing predicted $q_{u}$ values with measured $q_{u}$ values. 


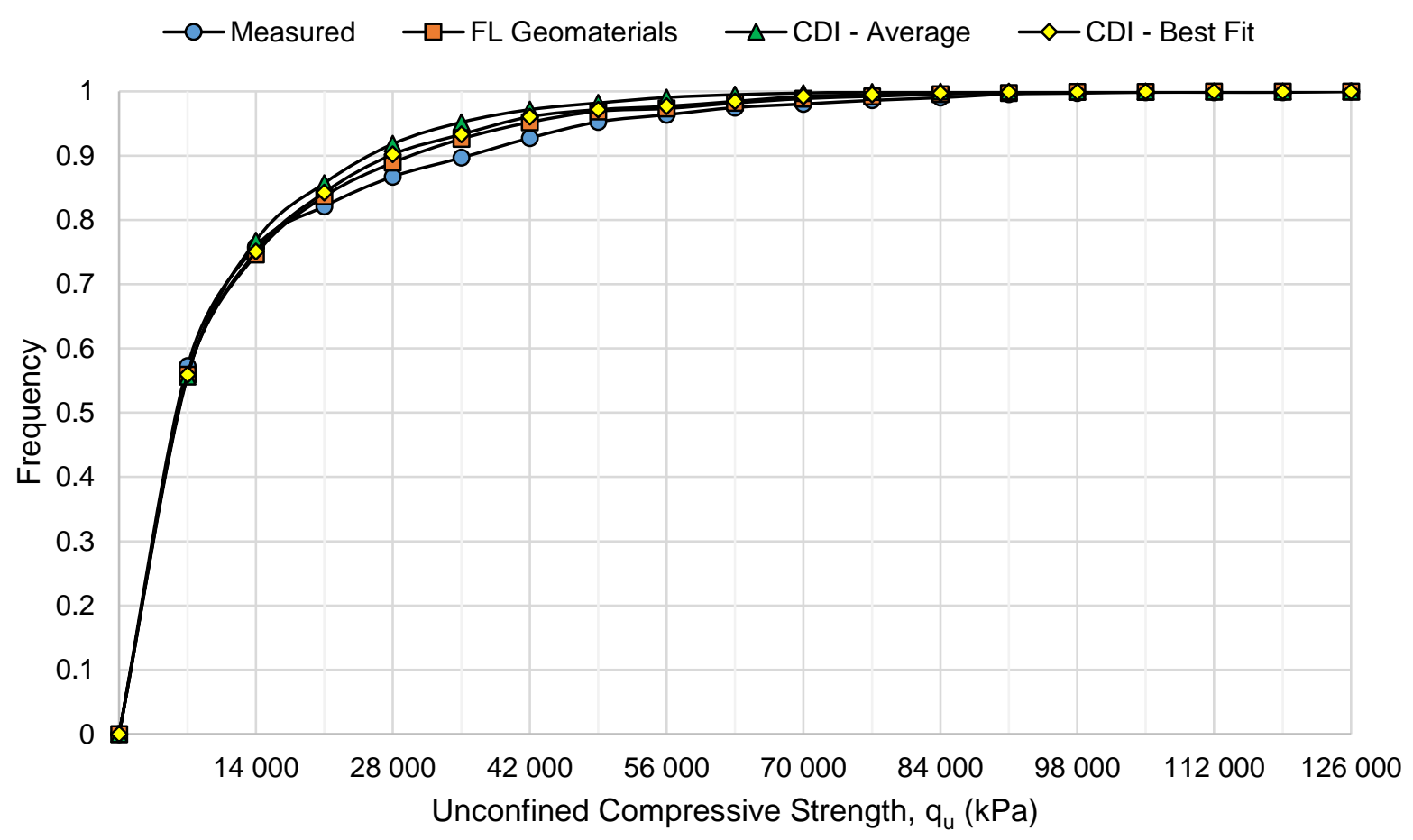

Figure 13. Cumulative Frequency distribution comparing predicted $q_{u}$ values with measured $q_{u}$ values. 


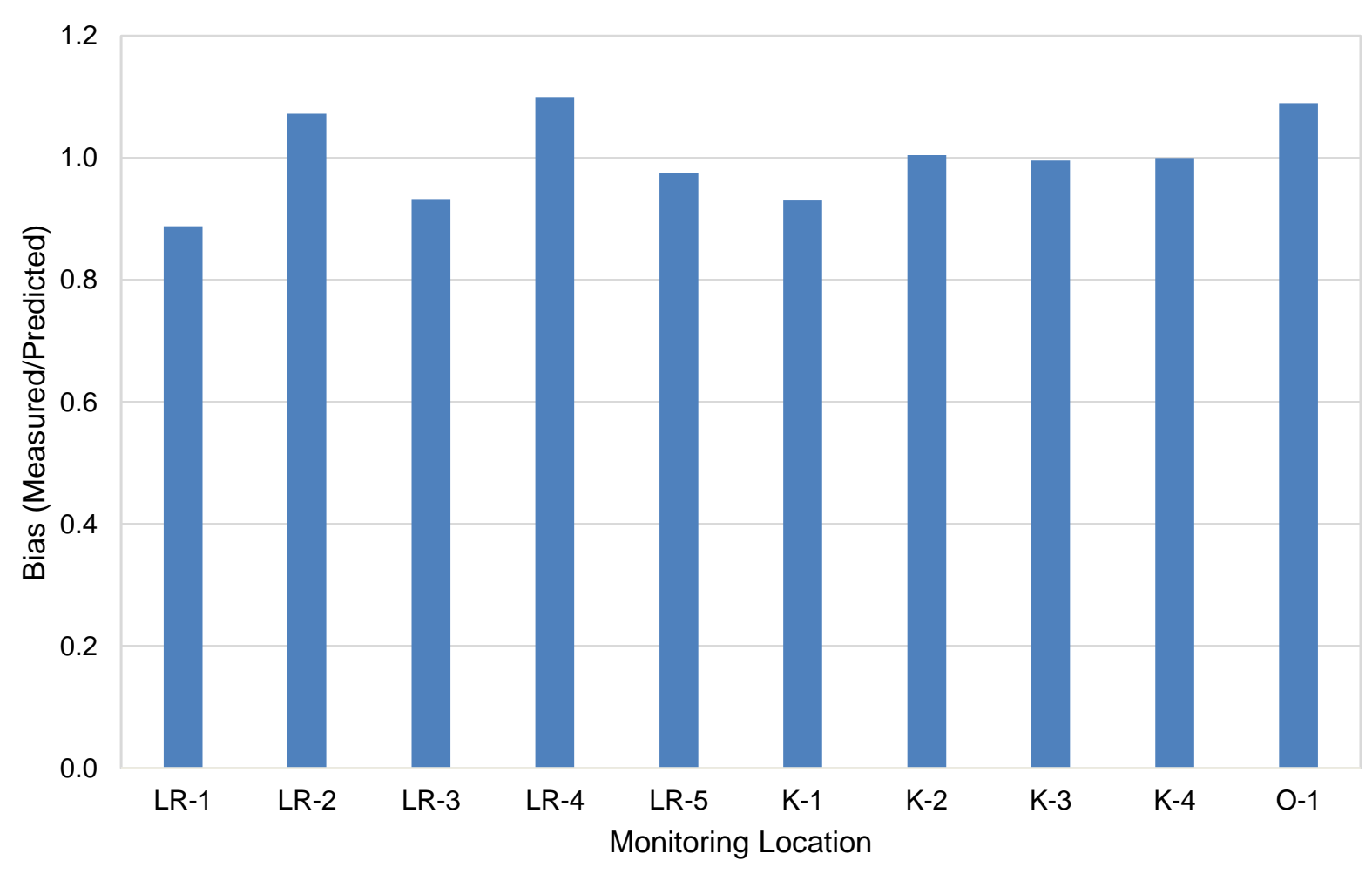

Figure 14. Unit side shear bias analysis Measured/Predicted (Load Test/Monitoring). 